НАУКОВО-МЕТОДИЧНІ ОСНОВИ ФОРМУВАННЯ ПІЗНАВАЛЬНОЇ САМОСТІЙНОСТІ УЧНІВ У ПРОЦЕСІ ВИВЧЕННЯ ГЕОГРАФІЧНОГО КУРСУ «УКРАЇНА I СВІТОВЕ ГОСПОДАРСТВО»

\title{
SCIENTIFIC AND METHODOLOGICAL FUNDAMENTALS OF FORMATION OF COGNITIVE INDEPENDENCE OF STUDENTS IN THE PROCESS OF STUDYING THE GEOGRAPHICAL COURSE "UKRAINE AND THE WORLD ECONOMY"
}

УДК 37.211

DOI https://doi.org/10.32843/2663-

$6085 / 2020 / 28.17$

\section{Яковлева В.А.,}

канд. пед. наук,

доцент кафедри екології та географрії

Житомирського державного

університету імені Івана Франка

Власенко Р.П.,

канд. біол. наук,

доцент кафредри екології та геограсрії

Житомирського державного

університету імені Івана Франка

Костюк В.C.,

канд. біол. наук,

доцент кафедри екології та геограсрії

Житомирського державного

університету імені Івана Франка

Андрійчук Т.В.,

канд. біол. наук,

доцент кафедри екології та геограсрії

Житомирського державного

університету імені Івана Франка у статті розкриваються науково-методичні основи фрормування пізнавальної самостійності учнів у прочесі вивчення курсу «Україна і світове господарство». Зокрема, наголошується, що в цьому курсі основною рисою є його життєпридатність, основною метою - ознайомлення учнів із реальним життям у навколишньому середовищі, для формування в них цілісного уявлення про людину, їі місце і роль у біосфрері, а також місця України у розв'язанні глобальних проблем людства. Розкривається сутність таких понять, як практичні принципи методики формування пізнавальної самостійності та рівнів сорормованості пізнавальної самостійності. Висвітлюються загальні теоретичні аспекти трикомпонентної технології як науково-методичного підгрунтя формування пізнавальної самостійності старшокласників, сучасні методики викладання курсу географрії «Україна і світове господарство». Звертається увага на методичний і дидактичний потенціал навчальних ігор як можливості ефеективної організації взаємодії педагога і учнів з елементами змагання та співробітництва, проблеми розвитку пізнавальної самостійності учнів у практиці педагогічної діяльності вчителів Житомирщини. Зазначається, що для реалізації зазначеного алгоритму мають бути виконані методичні вимоги: знання внутрішньої структури класу, вікових та індивідуальних характеристик учнів класу; високий рівень знання змісту та методики викладання геограсрії; знання специсріки групової навчально-пізнавальної діяльності; вміння забезпечувати групову проєктну діяльність необхідними методичними матеріалами, а реалізація розробленої технології вивчення курсу буде успішною: чіткої постановки ігрового проектного завдання перед старшокласниками з боку вчителя географрії; відповідності сфооммульованого завдання віку учнів і рівню розвитку їх пізнавального інтересу до курсу; дотримування принципу систематичності й послідовності в ході формулювання завдання та його виконання; взаємозв'язку різних видів самостійної пізнавальної діяльності; використання можливостей зв'язку урочної й позаурочної самостійної пізнавальної діяльності.

Ключові слова: методика, пізнавальна самостійність, ігрові, проєктні, комп'ютерні технології.
The article reveals the scientific and methodological foundations of the formation of students' cognitive independence in the process of studying the course "Ukraine and the World Economy". In particular, it is emphasized that in this course the main feature is its viability; The main goal is to acquaint students with real life in the environment, to form in them a holistic view of man, his place and role in the biosphere, as well as the place of Ukraine in solving global problems of mankind. The essence of such concepts as practical principles of a technique of formation of cognitive independence and levels of formation of cognitive independence is opened. The following are covered: general theoretical aspects of three-component technology as a scientific and methodological basis for the formation of cognitive independence of high school students; modern methods of teaching the course of geography "Ukraine and the world economy". Attention is paid to the methodological and didactic potential of educational games as opportunities for effective organization of interaction between teacher and students with elements of competition and cooperation; problems of development of cognitive independence of students in the practice of pedagogical activity of teachers of Zhytomyr region. It is noted that for the implementation of this algorithm must meet the methodological requirements: knowledge of the internal structure of the class, age and individual characteristics of students in the class; high level of knowledge of the content and methods of teaching geography; knowledge of the specifics of group learning activities; the ability to provide group project activities with the necessary methodological materials, and the implementation of the developed technology of studying the course will be successful: a clear statement of the game project task for high school students by a geography teacher; correspondence of the formulated task to the age of students and the level of development of their cognitive interest in the course; adherence to the principle of systematicity and consistency in the formulation of the task and its implementation; the relationship of different types of independent cognitive activity; use of opportunities for communication of classroom and extracurricular independent cognitive activity.

Key words: methods, cognitive independence, game, project, computer technologies.
Постановка проблеми в загальному вигляді. Науково-методичні основи вивчення курсу «Україна і світове господарство» ґрунтуються на концепції шкільної географрічної освіти XXI століття. Основною рисою курсу географрії у старших класах $€$ її життєпридатність, основною метою - ознайомлення учнів з реальним життям у навколишньому світовому середовищі - соціально-економічному, суспільно-політичному, геоекологічному. Географрія дає змогу школяреві ссрормувати цілісне уявлення про людину, їі місце і роль у біоссрері, можливі наслідки нераціональної господарської діяльності, а також про місце України у розв'язанні глобальних проблем людства. У зв'язку з цим 
шкільний курс геограсрії «Україна і світове господарство» виконує такі головні функції: пізнавальну, освітньо-виховну, інорормаційну, аналітично-пояснювальну, світоглядну, інтегративну, комунікативну, культурологічну, діяльнісну.

Як навчальний предмет «Україна і світове господарство» має широкі можливості для розвитку соціальної компетентності старшокласників, а саме: інтеграції профресійно і соціально значущих знань і надання їм практично орієнтованого характеру; сорормованості навичок спілкування 3 іншими людьми і внаслідок цього вміння самостійно здобувати знання, творчо опрацьовувати їх, використовувати для вирішення самостійних завдань.

Курс «Україна і світове господарство» покликаний сприяти формуванню системи знань про світовий географічний простір і загальнопланетарні процеси його розвитку, територіальну організацію національного та світового господарства, визначення місця і ролі України в сучасному світі [1].

Аналіз останніх досліджень і публікацій. У зв'язку з цим проблема фрормування пізнавальної самостійності 3 часом не лише не втрачає своєї значущості, а й стає дедалі актуальнішою для вивчення сучасною психолого-педагогічною наукою. Деякі аспекти цієї проблеми досить добре розроблені вітчизняними і зарубіжними географами-педагогами: доктором економічних наук Я.Б. Олійником, професором, доктором географічних наук А.В. Степаненко, професором, доктором географрічних наук О.Г. Топчієвим, профресором, доктором географрічних наук О.І. Шаблієм, а також провідним американським вченим, профресором Г. де Блія та профресором П. Муллером.

Проблему розвитку пізнавальної самостійності учнів у процесі вивчання географії розглядають вітчизняні учені-методисти і педагоги-практики В. Андреєва, О. Варакута, П. Вірченко, Л. Вішнікіна, М. Врублевська, Л. Гарус, Т. Герасим'юк, В. Гудима, Т. Довгань, С. Капіруліна, С. Кобернік, Т. Назаренко, О. Стадник, О. Топузов, Л. Тименко, С. Чернякова, Л. Шилова, А. Шуканова та ін.

Виділення не вирішених раніше частин загальної проблеми. Спостереження за організацією навчально-пізнавальної діяльності в загальноосвітніх школах дає змогу засвідчити, що головним недоліком у системі засвоювання знань із соціально-економічної географії світу $€$ недостатнє уміння старшокласників самостійно здобувати знання, а також переважання управлінських регулятивних засобів впливу на процес пізнавання.

Проблемі формування пізнавальної самостійності учнів у процесі вивчання географрії в загальнометодичному плані присвячено багато праць. У той же час при вивченні курсу «Україна і світове господарство» це питання ще мало висвітлено.
Поза детальним науковим аналізом поки що залишаються такі аспекти проблеми, як інформаційнотехнологічне забезпечення процесу формування пізнавальної самостійності, використання сучасних технологій навчання для розвитку пізнавальної самостійності учнів у процесі вивчення курсу географрії «Україна і світове господарство». У цьому контексті цей курс має незаперечний потенціал до фрормування пізнавальної самостійності у змістовому (зміст навчального курсу, орієнтований на вивчення глобальних геоекономічних, геосоціальних, геополітичних і геоекологічних процесів людства) та віковому (специоріка старшокласників як вікової групи) відношенні. Крім того, соціальні й економічні знання, закладені в програму дисципліни «Україна і світове господарство», дають змогу підвищити рівень соціальної, економічної та особистісної компетентності старшокласників, оскільки акцентують на умовах загальнолюдського співжиття [2].

Виклад основного матеріалу. Методика фрормування пізнавальної самостійності, на нашу думку, має ґрунтуватися на деяких практичних принципах їі реалізації, а саме:

1) принцип свободи вибору. Він реалізовується у тому, що в будь-якій навчальній пізнавальній діяльності учневі має бути надана максимальна свобода вибору - завдання, способу вирішення, навчальних засобів, інформаційних ресурсів тощо;

2) принцип відкритості процесу розвитку пізнавальної самостійності, який може бути реалізований у таких правилах: а) виводити завдання з соціально-економічної географії за межі навчальної дисципліни; б) використовувати відкриті завдання, з різними варіантами вирішення;

3) принцип діяльності - намагатися закріпити виконану навчальну роботу в практиці діяльності, в застосуванні;

4) принцип зворотного зв'язку: контроль засвоєння навчального матеріалу з географії у старших класах шляхом розвитку пізнавальної самостійності повинен мати розвинуту систему прийомів зворотного зв'язку;

5) принцип високого коефіцієнта корисної дії самостійних пізнавальних завдань, прорахованого в індивідуальному порядку для кожного учня [2].

У методиці й дидактиці виділяють, як правило, кілька головних рівнів сорормованості пізнавальної самостійності - реконструктивно-варіативний, відтворення, частково-пошуковий та творчий (Т. Шалавіна). В. Архипов пропонує виокремлювати такі рівні: репродуктивної самостійності, реконструктивно-варіативної самостійності, творчої самостійності. Д. Ахметова і В. Габдулхаков виділяють такі рівні пізнавальної активності нульовий, ситуативний, виконавський, творчий [3].

Досягнення результату пізнавальної діяльності й пов'язаний із цим розвиток пізнавальної само- 
стійності відбувається як двоєдиність процесів інтеріоризації (засвоєння методів і способів самостійної пізнавальної діяльності) та екстеріоризації (застосування самостійно-пізнавальних умінь, сорормованих у процесі виконання одного пізнавального завдання для виконання іншого).

Проблема розвитку пізнавальної самостійності учнів при вивченні предмета «Україна і світового господарства» значною мірою реалізована у практиці педагогічної діяльності вчителів Житомирщини. Вони творчо осмислюють можливості географії в розвитку методики формування пізнавальної самостійності старшокласників.

У процесі дослідження нами проаналізовано науково-методичну діяльність учителів географрії та основ економіки в різних регіонах Житомирщини. Так, О.М. Глушенко, вчитель географії загальноосвітньої школи № 5 м. Житомира, покладає процес розвитку пізнавальної самостійності старшокласників при вивченні географрії на фрормування в них ключових компетенцій. При цьому педагог застосовує притаманні розроблені нами технології: ігрові технології (наприклад, географрічну гру «що? Де? Коли?»), уроки-конференції, уроки захисту власної думки тощо.

О.М. Глушенко вважає базовими вміннями старшокласників у процесі вивчення географрії в курсі «Україна і світове господарство» уміння моделювати навчальну інфрормацію, складати схеми, проектувати символи за допомогою прийомів відтворення, узагальнення, прогнозування.

У процесі застосовування ігрових технологій характеризуються і методичні підходи до викладання географії з боку вчителя географії К3 «Чуднівський ліцей» Л.М. Макарчук. Ігрові фрорми роботи у вигляді уроків-прес-конореренцій реалізовує у своїй діяльності Л.В. Очеретна - вчитель географії Тютюниківської ЗОШ I-ІІІ ступеня. Такий урок передбачає самостійну підготовку учнів до нього в спеціально створених з учнів групах демографрів, істориків, географрів, економістів, тобто дає змогу розвивати пізнавальну самостійність старшокласників, реалізовуючи при цьому міжпредметні зв'язки.

Учитель географрії та основ економіки Л.С. Криворучик КЗ «Чуднівська гімназія» використовує на уроках географрії з курсу «Україна і світове господарство» інтерактивні фрорми роботи - презентації виконаних самостійно учнями робіт, роботу в малих групах, експрес-опитування, роботу експертної групи, що складається з 3-4 учнів, для оцінювання самостійної пошукової діяльності учнів під час підготовки до уроку [4]. Учні також готують короткі повідомлення для виголошення на уроці, застосовуючи пошукові методи роботи.

Учитель Високопічської ЗОШ № 1 Житомирської області П. Пухтаєвич головну увагу приділяє застосовуванню на уроках географії «Україна і світове господарство» комп'ютерних технологій. Педагогметодист вважає, що можливості комп'ютера на уроках геограсрії досить потужні, а саме: демонстрація об'єктів; моделювання географрічних процесів; виконання старшокласниками практичних робіт (із побудовою графріків, діаграм, схем); перевірка знань старшокласників (комп'ютерні тестові завдання); проведення презентацій (за допомогою програми PowerPoint), яке може відбуватися, на думку педагога, як самими учнями, так і з допомогою вчителів географії та інформатики; самостійна пошукова робота старшокласників у мережі Інтернет. П. Пухтаєвич пропонує педагогам і учням використовувати підібрані ним вебсайти з географрічної проблематики. Зауважимо принагідно, що із запропонованих ним ресурсів лише 5 розроблені в Україні, інші -німецькомовні та англомовні.

Учитель географрії та основ економіки Чудівського району Вільшанської ЗОШ I-III ступеня 3.В. Тичинська пропонує пов'язувати викладання курсу географрії «Україна і світове господарство» з вивченням учнями основ інфрорматики, справедливо вважаючи, що при цьому пізнавальна самостійність старшокласників буде розвиватися краще [5]. Метою таких бінарних уроків педагог вважає фрормування у старшокласників уміння і навички аналізувати і систематизувати, висловлювати свої думки та ідеї, захищати свої позиції, фрормулювати проблемні запитання і самостійно шукати на них відповіді. Схожий підхід пропонують застосовувати для розвитку пізнавальної самостійності учнів учителі ЗОШ № 5 м. Житомира І.Л. Андрощук та Я.М. Федоренко, практикуючи інтегровані уроки геограсрії та хімії.

Частина вчителів географії, чий досвід було вивчено в процесі дослідження, пов'язує розвиток пізнавальної самостійності учнів зі створенням інноваційного навчально-методичного забезпечення переважно у вигляді інформаційно-технологічних продуктів (комп'ютерних програм, презентацій, електронних атласів) та робочих зошитів.

До прихильників такого шляху фрормування пізнавальної самостійності ми зараховуємо вчителів географії та основ економіки ЗОШ № 26 м. Житомира О.В. Себало, С.М. Войналович (Житомирський міський ліцей при державному технологічному університеті), Т.Д. Магалецька (загальоосвітя школа № 28), М.В. Медвєдєва (Житомирський міський ліцей при ЖДТУ), Л.М. Сидорчук (міський ліцей № 2 м. Житомира), Я.І. Лех (загальноосвітня школа № 27 м Житомира) та ін. Самостійні індивідуально-групові фрорми роботи на уроці географії (в тому числі із застосуванням методу дискусії) практикує учитель географрії та економіки Н.І. Сатир (спеціалізована школа № 20 м. Житомира).

Це дослідження ґрунтується на використовуванні методичного потенціалу трикомпонентної 
технології вивчення географії, що має у своєму складі інтерактивні фрорми навчально-пізнавальної діяльності (ігрові технології, дискусійні фрорми роботи тощо), методики проєктування і створення мультимедійних комп'ютерних презентацій за заданим проектом і вибраною навчально-пізнавальною грою. При цьому ми виходимо з наукових розроблень В. Корнєєва стосовно того, що технологія у вивченні географії реалізується в різних формах процесу навчання географії, до яких належать і ті, що пропонуємо ми як трикомпонентну технологію вивчення соціально-економічної географрії світу.

Натомість тут розглянемо загальні теоретичні аспекти цієї технології як науково-методичного підґрунтя фрормування пізнавальної самостійності старшокласників під час вивчення географії.

Інноваційна технологія, на думку науковців, уможливлює побудову продуктивного процесу формування пізнавальної самостійності старшокласників. Як відомо, продуктивне навчання - це практично втілений процес особистісно орієнтованого навчання, побудований на засадах вільного вибору і навчальної зацікавленості учнів у вивченні географії. Виконанню цілей продуктивного навчання сприяє робота старшокласників у малих групах, що дає змогу реалізувати ефективну проектну діяльність. При цьому враховуються індивідуально-психологічні особливості кожного 3 учасників трикомпонентної технології. Так, у розроблянні проєкту старшокласники мають змогу реалізувати себе як учасники гри, розробники проєкту, організатори або виконавці. Крім того, в реалізації такої трикомпонентної моделі виявляються необхідні міжпредметні зв'язки: 3 математикою, інфрорматикою тощо.

Таким чином, у своїй основі ця трикомпонентна технологія $є$ груповою фрормою пошуково-дослідницької роботи старшокласників, яка сприяє розвитку пізнавальної самостійності. Додамо, що така технологія може бути використана в курсі не лише географії, а й в інших навчальних предметів. Пізнавальна самостійність при цьому реалізовується у фрормі пізнавальної активності. Сутність останньої полягає у тому, що учень у процесі аналізу, порівняння, синтезу, узагальнення і конкретизації навчального матеріалу 3 географрії одержує нову навчальну інфрормацію самостійно і вже на її основі знову застосовує методи аналізу, синтезу, порівняння і т. д.

Розглянемо детальніше виокремлені нами три компоненти технології вивчення географії, що дають змогу фрормувати в старшокласників стійку пізнавальну самостійність.

Інтерактивні фоори і методи навчально-пізнавальної діяльності в процесі вивчення суспільногуманітарних дисциплін розглянуто в працях О. Кравчиної, М. Врублевської, Т. Герасим'юк,
О. Пометун, Л. Пироженко, Т. Хлєбнікової та ін. При цьому науковці доходять висновку, що інтерактивне навчання сприяє засвоєнню навчального матеріалу, оскільки впливає не лише на свідомість учня, а й на його почуття, волю, а отже, на його дії та практику. Інтерактивні фрорми навчання передбачають взаємодію, співпрацю, групову роботу, дискусії, рольові ігри, моделювання ситуацій, індивідуальні й групові творчі завдання тощо.

У межах завдань цього дослідження ми пропонуємо розглядати серед найдоцільніших інтерактивних форм та методів розвитку пізнавальної самостійності учнів ігрові та дискусійні. Гра явище багатогранне, її можна розглядати як особливу фрорму існування усіх без винятку сторін життєдіяльності дитини, колективу. Гра є ефективним засобом формування особистості дитини, їі морально-вольових якостей. У грі реалізовується потреба впливу на світ. Вона сприяє розвитку пам'яті, уявлення, позитивних емоцій та вольових якостей особистості, а також вчить дитину управляти своїми емоціями, організовувати свою діяльність. Необхідно звернути увагу на те, що у випадку навчально-пізнавальної гри з географії, в основу якої покладено навчально-пізнавальне завдання, наче накладається на суб'єктивний досвід учнів. Відбувається інтеграція попереднього досвіду засвоєння знань на засадах пізнавальної самостійності, тому легко засвоюється і стає звичним нове і складне знання.

Сучасна методика викладання окремих навчальних дисциплін цілком обґрунтовано звертається до методичного і дидактичного потенціалу навчальних ігор як можливості ефективної організації взаємодії педагога і учнів з елементами змагання та співробітництва. Ставлення учителів географрії до ігрових технологій неоднозначне: деякі наполягають на результативності їх, інші віддають перевагу традиційним методам навчання. Серед переваг ігрових технологій педагоги зазначають, насамперед, зростання пізнавального інтересу і пізнавальної активності, ефективніше засвоєння навчального матеріалу, об'єднання учнівського колективу, розвиток мислення, до недоліків ігор - складність в організації, тривалість за часом, складність в оцінюванні учнів. Ігри справляють сильний емоційний вплив на старшокласників, сприяють фрормуванню значущих умінь і навичок, насамперед, комунікативних, а також уміння працювати в групі, брати відповідальність за прийняті рішення тощо.

Головними компонентами навчальної гри, як свідчить аналіз наукових джерел, є ігровий задум, правила гри, ігрові дії, пізнавальний зміст гри, необхідне обладнання гри, результат гри. Ігровий задум окреслюється її назвою і головним завданням гри, яке виступає у ролі навчальнопізнавального завдання. Правила гри розробля- 
ються 3 урахуванням загальної мети (у цьому випадку - пізнавальної мети проєкту з географії) та індивідуальних особливостей старшокласників. Це забезпечує вияв пізнавальної активності, творчості, самостійності учнів і реалізується в ігрових діях. Результатом навчальної гри у цьому випадку $\epsilon$ виконане навчально-пізнавальне завдання завершений проєкт і його презентація для усього класу. Вплив ігрових методик на орормування пізнавальної самостійності у процесі вивчання соціально-економічної географії полягає у тому, що: старшокласників залучають до уявної життєвої ситуації; вони актуалізують свій суб'єктний досвід; учні мають змогу знайти практичне застосування для засвоєних у процесі вивчення географії знань; у процесі навчально-пізнавальної гри розвивається пізнавальна активність.

Дискусія як форма і метод розвитку пізнавальної самостійності учнів у процесі вивчання курсу «Україна і світове господарство», на нашу думку, виконує роль каталізатора власних думок і суджень старшокласника під час вивчення певного навчального предмета. О. Герман вважає навчальну дискусію на уроках географії, побудовану на засадах компетентністного підходу, «однією з найефективніших форм, що допомагає підростаючому поколінню в пошуку нових знань та орієнтирів для наступного самостійного дорослого життя». Науковець вбачає у дискусії фрорму реалізації суб'єкт-суб'єктних відносин, оскільки для успішного ії проведення 3 метою розвитку пізнавальної самостійності школярів певні фрункції має реалізувати і вчитель (вибір теми відповідно до дидактичних завдань, підготовка джерел інорормації та інструктивного матеріалу, прогнозування вирішення проблеми, консультування учнів, здійснення мотивації, корекція, моніторинг), і учні (оволодіння прийомами роботи 3 додатковими джерелами інформації; обмін знаннями, що здобуті самостійно; розвиток комунікативних навичок; усвідомлення емоційно-вольових характеристик; розвиток уміння відстоювати власну точку зору; набуття толерантності до думки інших учасників дискусії; рефлексія). Доцільно запропонувати для уроків географії такі, наприклад, теми дискусій: «Інорорматизація й глобалізація - благо для сучасного світу», «Європа - арена глобальних політичних, соціальних та екологічних конфрліктів», «Антропосфрера - інструмент самознищення» та ін.

Метод проєктів знайшов широке застосування у вітчизняній педагогічній науці, починаючи 3 початку XX століття. Тому можемо погодитися 3 В. Корнєєвим стосовно того, що вважати його повністю інноваційним і новим не можна, однак характеристики його реалізації завжди вимагають інноваційних підходів. Суттєва відмінність застосовування методу проєктів у нинішніх умовах полягає в тому, що він реалізується в принципово іншому інфрормаційному середовищі, оснащеному комп'ютерною технікою.

Формування пізнавальної самостійності учнів $€$ одним із головних завдань методу проєктів. Він має розвивати у старшокласників уміння самостійно здобувати знання і поєднувати їх в єдину систему. Невипадково В. Корнєєв вважає, що в межах використання методу проєктів «вчитель спрямовує діяльність учнів на самостійне перенесення знань для опрацювання нової інфрормації, здатність передбачати можливі наслідки рішень, що приймаються, встановлення причинно-наслідкових зв'язків».

У психолого-педагогічній науці проєкт - це деякий конкретний напрям роботи дітей для створення реального практичного чи теоретичного продукту. Метод проєктів реалізується в навчально-пізнавальних ситуаціях, коли необхідним $€$ розв'язування проблеми із залученням різноманітних методів, засобів навчання з різних галузей знань. Завданням і результатом методу проектів $€$ розвиток пізнавальної активності й самостійності учнів.

Перевага проєктної методики в процесі формування пізнавальної самостійності старшокласників полягає ще й у тому, що проєкт створюється в мікрогрупах. Завдяки ж груповій навчально-пізнавальній діяльності успішно реалізуються розвиваючі цілі навчання. Діяльність у групі справляє найефективніший вплив на мислення школярів, тим самим на їх пізнавальну самостійність. Прискорюються асоціативні процеси, розширюються пізнавальні інтереси учасників групового проєкту, узагальнюються і систематизуються уявлення, стимулюється аналітико-синтетична навчальнопізнавальна діяльність.

У науково-педагогічній літературі виділено такі головні типи проєктів: за домінуючою діяльністю (інорормаційні, дослідницько-творчі, прикладні); за часом розроблення та виконання їх (короткотермінові (планування, реалізація і рефлексія проекту здійснюються в межах одного уроку), й тривалі (від кількох уроків до кількох місяців)); за кількістю учасників проєкту (індивідуальні, групові й колективні); за ступенем пізнавальної самостійності учнів (під повним управлінням учителя; на правах партнерства з учителем; повністю самостійні).

Проєкт, який ми пропонуємо покласти в основу трикомпонентної технології вивчення України і світового господарства, є, таким чином, груповим тривалим проєктом, що здійснюється на правах партнерства і суб'єкт-суб'єктних відносин з учителем. Крім того, проєкт може поєднувати інформаційні й творчі характеристики, або ж дослідницькі й практико-орієнтовані. Розглянемо детальніше названі нами основні типи проєктів [4]. 
Інформаційний проєкт - це вид проєктного продукту, спрямованого на збирання нової пізнавальної інсрормації з наступним ії̈ аналізом, узагальненням і можливою мультимедійною презентацією. Для планування цього проєкту необхідно визначити: об'єкт збирання інформації (наприклад, соціально-економічне становище країн Африки); можливі джерела одержання навчальної інфрормації (підручники, посібники, відеоматеріали, Інтернет тощо); форми представлення результату (комп'ютерна презентація, як це передбачено трикомпонентною технологією).

У контексті проблеми цього дослідження завданням інфрормаційного проекту $\epsilon$ фрормування умінь самостійно знаходити, опрацьовувати і подавати навчальну інфрормацію в заданому вигляді. Інформаційний проєкт може стати творчим, дослідницьким чи практико орієнтованим.

Дослідницький проект вимагає визначення об'єкта і предмета дослідження, обґрунтування теми, висунення гіпотези, визначення джерел одержування необхідної інорормації тощо. Так, наприклад, дослідницький проєкт на тему «Соціально-економічний розвиток країн Афррики» передбачає такий науковий апарат, який мають самостійно або з допомогою учителя ссрормулювати учасники проєктної групи: Об'єкт аналізу економіка країн Афррики.

Предмет дослідження - головні характеристики соціального та економічного стану розвитку країн Африки. Гіпотеза дослідження - економічний та соціальний розвиток країн Афррики знаходиться в прямій залежності від економічного й соціального розвитку колишніх країн-колонізаторів цих нині незалежних держав. Необхідні джерела навчальної інфрормації - підручники, методичні посібники, мережа Інтернет, засоби масової інорормації. Дослідницький проєкт може бути конкурсним, поданим до участі на регіональному чи загальноукраїнському рівнях.

Практико орієнтований проект має на меті одержання реальних результатів роботи (наприклад, оформлення кабінету економічної географрії). У процесі виконання цей проєкт може стати дослідницьким чи перетворитися на творчий.

Прикладами практико орієнтованих проєктів можуть бути такі: проєкт вивчення наслідків господарської діяльності людини в економічному і соціальному просторі в різних регіонах світу; проєкт зі створення національних парків у різних куточках світу; проєкт створення науково-дослідницької станції в умовах екстремальної природної ситуації (біля кратера вулкана, в полярних умовах тощо).

Науковці вважають, що в старших класах пізнавальні проєкти мають бути практико орієнтованими, а головними вимогами до розроблення й презентації їх мають бути такі: орієнтація на чинну програму і навчальний план із соціально-економіч- ної географрії світу; зміст проєкту має бути логічним, доступним, із фрормулюванням практичних цілей і задач для старшокласників; у груповому проєкті має бути узгоджена практико орієнтована роль кожного з учасників; використання в проєкті відповідної наукової термінології, яка має практичне спрямування; вияв знань, практичних умінь і навичок учасників проєкту на доволі високому рівні; високий ступінь самостійності виконання практико орієнтованого проєкту.

На значущості методу проєктів для розвитку пізнавальної самостійності на уроках географії наголошує і М. Чанова, зазначаючи, що проєктування може посилити дослідницькі здібності учнів, мотивацію до здобування нових знань самостійно, актуалізувати групові фрорми роботи на уроках географріï.

Для визначення тематики проєктної діяльності вчителеві географії світу необхідно провести таку підготовчу методичну діяльність: проаналізувати зміст навчального матеріалу з географії та визначити базовий перелік знань і вмінь старшокласників, які мають бути сорормовані під час вивчення курсу; визначитися з вибором структурних компонентів проекту та алгоритмом виконання їх десятикласниками; визначити комплекс необхідного обладнання, навчально-методичних і програмних матеріалів; окреслити види і типи оцінювання проєктної діяльності школярів.

Для реалізації зазначеного алгоритму мають бути виконані й такі методичні вимоги: знання внутрішньої структури класу, вікових та індивідуальних характеристик учнів 9 класу; високий рівень знання змісту та методики викладання геограсрії; знання специфріки групової навчально-пізнавальної діяльності; вміння забезпечувати групову проєктну діяльність необхідними методичними матеріалами.

Використання новітніх комп'ютерних технологій у процесі вивчення географії нині відбувається у площині нової освітньої парадигми, що передбачає суб'єкт-суб'єктні відносини учасників освітнього процесу, побудовані на засадах особистісно орієнтованої педагогіки.

Таким чином, ця парадигма визначає необхідність розвитку пізнавальної самостійності старшокласників, без якої і суб'єкт-суб'єктні відносини, і особистісно орієнтований навчальний процес будуть неефективними.

На необхідності застосовування інформаційнокомп'ютерних технологій під час вивчення географрії наголошують і педагоги-практики. Так, учитель географії із загальноосвітньої школи № 26 О.В. Себало вважає, що використання сучасних інформаційних технологій у навчальному процесі розвиває пізнавальні здатності школяра, необхідні йому протягом усього подальшого життя.

Глобалізація інформаційно-освітнього середовища викликала проникнення сучасних інфор- 
маційних технологій в усі сфери людського життя, тому мультимедійні технології швидко впроваджуються і в освіту.

У контексті проблеми цього дослідження сучасні комп'ютерні технології сприяють самостійному засвоюванню учнями і педагогами нових знань, умінь і навичок, що сприяють вивченню геограсії, самоосвіті й самовдосконаленню особистості учасників освітнього процесу, розвитку позаурочної самостійної пізнавальної діяльності.

Комп'ютерні технології у географічній освіті мають суттєві переваги, якщо зіставляти традиційні та інноваційні методи викладання: комп'ютерні технології уможливлюють інтенсифікацію всього навчального процесу; поєднуються всі організаційні фооми навчально-пізнавальної діяльності - навчальні, контрольно-оцінювальні й самостійна робота; відбувається активізація пізнавальної діяльності, у зв'язку з чим зростає рівень пізнавальної самостійності; здобуті з використанням комп'ютера знання перетворюються на власні переконання; змінюється методика викладання географії, яка стає демократичнішою, послаблюється суб'єктивний чинник у контролі та оцінюванні знань учнів; у комп'ютерних технологіях закладено значні мотиваційні можливості до вивчення географрії, оскільки з'являється доступ до новітньої свіжої інформації, який може реалізуватися в ігровій формі; розширюються можливості самостійного вивчення географії; частка самостійної роботи серед інших форм навчання значно зростає.

Значущим методом формування пізнавальної самостійності учнів при вивченні геограсрії $€$ використання комп'ютерних технологій. Врахуємо, що В шкільному географічному курсі закладено значні можливості для використання комп'ютерних технологій.

У викладанні геограсії можна виділити кілька основних напрямів використання комп'ютерних технологій та мультимедіа: демонстрація наочних матеріалів; показ географрічних процесів; геоінфрормаційне навчання; контроль і перевірка засвоєння; комплекс завдань для розвитку пізнавальної самостійності учнів.

Демонстрація навчального матеріалу в курсі «Україна і світове господарство» відбувається переважно у формі показу настінних демонстраційних карт, які за допомогою комп'ютерної техніки можуть бути перетворені на медіапродукти, запозичені з мережі Інтернет або ж самостійно створені старшокласниками на підставі засвоєних ними навичок роботи в різних редакторах. Показ геограсрічних процесів із застосуванням комп'ютерної техніки може відбуватися у вигляді показу картографічнних проєкцій, побудови ізоліній і статистичних поверхонь, комп'ютерної побудови географрічних карт, зіставлення географрічних явищ тощо. Геоінформаційне навчання виявляється у старших класах у фрормі демонстрації та обговорення різноманітних геозображень (статичних, динамічних, плоских, об'ємних). Комп'ютерна техніка дає змогу компонувати ці об'єкти, працювати з їх розміром, розміщенням тощо.

Контроль і перевірка знань старшокласників із залученням комп'ютерної техніки $€$ важливим інструментом розвитку їхньої пізнавальної самостійності й може відбуватися у вигляді комп'ютерних тестів, індивідуальних самостійних завдань тощо.

Висновки. Виявлені науково-методичні основи формування пізнавальної самостійності старшокласників при вивченні курсу «Україна і світове господарство» засвідчили, що вони детерміновані концепцією геограсрічної освіти в школі. Тому методика формування пізнавальної самостійності має ґрунтуватися на системі принципів: свободи вибору, відкритості, діяльності, зворотного зв'язку, високого коефріцієнта корисної дії.

Встановлено, що науковці вирізняють різнорівневу структуру формування пізнавальної самостійності учнів у процесі вивчання ними різних навчальних дисциплін. Наведений вище аналіз науково-методичних основ формування пізнавальної самостійності школярів при вивченні курсу «Україна і світове господарство» свідчить, що реалізація розробленої нами технології вивчення географрії буде успішною за таких умов: чітка постановка ігрового проєктного завдання перед старшокласниками з боку вчителя географії; відповідність сорормульованого завдання віку учнів і рівню розвитку їх пізнавального інтересу до курсу географрії, дотримування принципу систематичності й послідовності в процесі фрормулювання завдання та його виконання; взаємозв'язок різних видів самостійної пізнавальної діяльності; використання можливостей зв'язку урочної й позаурочної самостійної пізнавальної діяльності.

\section{БІБЛІОГРАФІЧНИЙ СПИСОК:}

1. Кобернік С., Коваленко Р. Географрія для 9 класу : підручник. Кам'янець-Подільський : Абетка, 2017. 256 c.

2. Кобернік С. Методика викладання географії в школі : навч. метод. посібник. Стафед - 2. Київ, 2000. $320 \mathrm{c}$.

3. Шуканова А.А. Методика фрормування економічних знань в учнів 9-10 класів у процесі навчання географії : дис. ... канд. пед. наук : 13.00 .02 / Інститут педагогіки НПН України. Київ, 2009. 261 с.

4. Яковлева В.А. Формування пізнавальної самостійності учнів у процесі навчання соціально-економічної географрії світу : дис. ... канд. пед. наук : 13.00.02 / Інститут педагогіки НПН України. Київ, 2011. $228 \mathrm{c}$. 